\title{
PISMO JOSIPU VANIŠTI
}

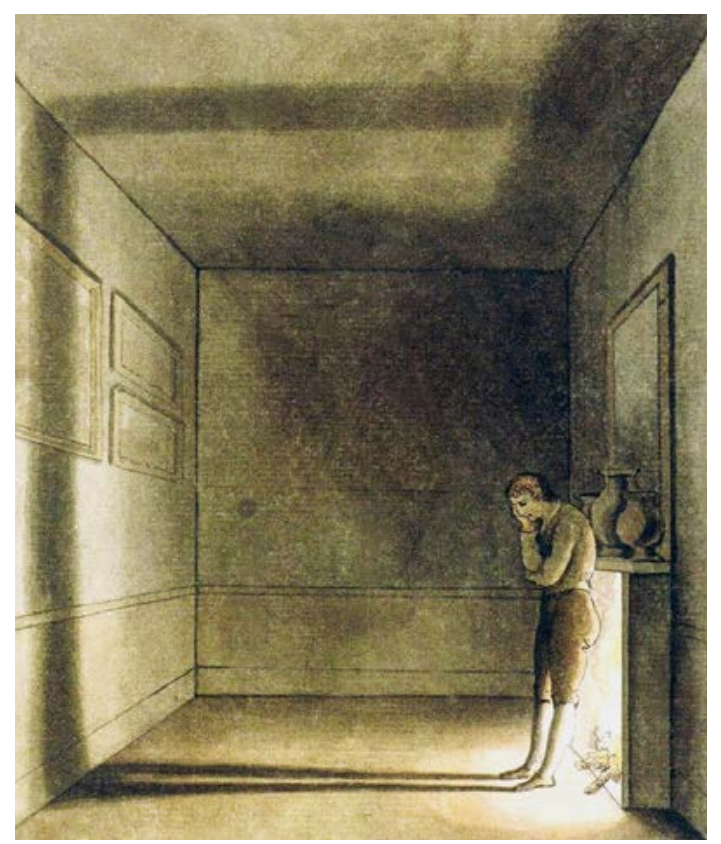

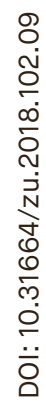

Leonida Kovač 
Poštovani gospodine Vaništa,

Vaša rečenica ispisana na petnaestom listu zvuči obvezujuće. No ipak: zbog njezine proturječnosti i neprihvaćanja metafizike utjehe.

Kažete da Laterna magica koju ste naslikali 1954. godine počiva već šezdeset godina u podrumu Moderne galerije u Rijeci. U miru.

Iz dostupne mi reprodukcije otisnute na polusjajnom papiru u njoj tražim ekstenziju toga puta na kojem putnika nema. U paradoksalnoj, istodobno stvorenoj i dokinutoj perspektivi. U later(n)alnom otvaranju, bez točke iščezavanja na horizontu udaljenom devetnaest nautičkih milja od Livorna ili, prevedeno u kronometrijske termine, sat i pol putovanja trajektom. Koliko bi bilo potrebno jedrenjakom? Ili čamcem na vesla?

Zapisali ste da njezina pažnja prelazi s bitka spram privida i da je postojana u sumnji. Spomenuli ste njezine tajanstvene boli i naglasili da ona ne govori ni o čemu. Podcrtali ste to crvenom linijom stamenijom od plahih rukopisnih slova. Crvenom poput one u kvadraturama Laterne magice i one diluvijalne što preplavljuje Studiju prema Masacciu, naslikanu iste godine kad Resnais snima Toute la mémoire du monde i otvara je tvrdnjom da čovjek zbog vlastitoga kratkog pamćenja akumulira bezbrojna pomoćna sjećanja. Slikati je pomirenje s nesrećom, pišete. Možda baš zato.

Sve sam sklonija ne vjerovati u slučajnost slučaja. Sinoć su me Vaše rečenice i Laterna magica navele na ponovno gledanje filma; danas sam u talijanskim novinama pročitala vijest o redateljevu prijelazu u nedokučivu dimenziju. Putnik na putu. Ako ga ne vidimo, znači li to da ga nema? Hvala što niste ništa rekli. Težinu rečenice s petnaestog lista tek kasnije otkrivam u Vašem razgovoru s Ješom. U odgovoru na pitanje o praznini što je zapravo odgovor pitanjem koje je Vama uputio Der alte Fritz. Marienbad ili Balaton? Nescimus horam neque diem.

Resnaisova Bibliothèque nationale de France figuracija je jezovite ili, možda preciznije, čudovišne perspektive ispisane trajno umnažajućim kubusima i rešetkama: beskonačnim hodnicima. (U analogan će nas ponor na samom izmaku dvadesetog stoljeća uvrtložiti Matrix braće Wachowski.) U jednom kadru perspektiva usisava bibliotekara koji na ramenu nosi ogromnu inventarnu knjigu. Nošenje knjige podsjetilo me na Vaš čin polaganja Crne linije na srebrnoj pozadini u snijeg jelenovačke šume. (Iste godine kada je Jarman snimio Caravaggia. No hope, no fear.) U krupnom planu Resnaisova filma pojavljuje se i jedna druga knjiga uvezana u kartonske šatirane korice poput onih s Pascinove knjižice koju ste neki dan, nakon sedamdesetogodišnje posudbe, uz popratno pismo vratili zagrebačkoj Akademiji likovnih umjetnosti. Dok slika pokazuje platneni hrbat debele knjige na kojemu piše Zola, glas naratora govori da se, među ostalim, u Bibliothèque nationale nalaze i sabrana djela Émilea Zole.

Četvrtim listom posvajate misao Emila Ciorana. Ispisujete je ovako:

Od desete do četrnaeste godine stanovao sam u konviktu.

Svako jutro na putu u školu prolazeći mimo knjižare nisam propuštao baciti pogled na knjige

koje su u izlogu često mijenjali u malom rumunjskom gradu. Jedna je bila zaboravljena, 
Taj naslov jedina je uspomena iz tih godina

koja me opsjeda

- E. M. Cioran

Postoji jedna fotografija na kojoj ste snimljeni Vi, leđima okrenuti kameri, pred izlogom knjižare Znanje u Zvonimirovoj ulici koja se tada zvala Ulica socijalističke revolucije. $U$ izlogu promatrate fotografiju koju ste režirali i nazvali je Levitacija. Snimio ju je Ante Vulin na Vašoj izložbi u Galeriji suvremene umjetnosti 1988. godine. Uzdignuti od tla poput iluzionista, napola zaklonjeni masivnim dovratnikom predzadnje sobe Kulmerove palače, odjeveni u isti kaput, isti šešir i držeći u ruci istu onu aktovku koju držite i pred izlogom knjižare, zakoračili ste prema svojem izloženom crtežu olovkom naslovljenom Perspektiva u kojemu se, kao i u klasičnom poučku, pričinja da će se izmičuće paralelne linije susresti u točki iščezavanja.

U Čovjeku zvijeri sve se zbiva oko paradigmatičnoga perspektivnog modela: željezničkih tračnica. Zolin je roman, premda ne tako eksplicitno kao Dreyfusova afera, nagovijestio tračničku perspektivu dvadesetog stoljeća, perspektivu nemislivoga i neizrecivoga, onoga što nije moguće naslikati ni u pomirenju s nesrećom, perspektivu u kojoj ni Cioran ni Montherlant nisu ostali nedužni. Smijem li Vas pitati, jeste li je zato ukinuli?

U Levitaciji, vjerojatno zbog osebujne ekspozicije, Vaš se lik doima poput figure iz kazališta sjena. Ta ista, ali ne i identična kontura, kontura velike sjene prelomljenog koraka u međuprostorima knjižare, pločnika i stakla izloga pred kojim stojite, postat će neodvojiva od Vašeg pogleda na Levitaciju. Njezin će šešir zaposjesti desni donji kut fotopapira: mjesto na kojemu bi se, prema konvencijama u slikarstvu, trebao nalaziti potpis autora.

U ovoj knjižici, kao šesnaestu misao (za mjesec, godinu, desetljeće ili stoljeće, posve je svejedno) objavljujete reprodukciju akvarela Goetheova suputnika Johanna Heinricha Wilhelma Tischbeina. La grande Ombre nastala je oko 1805. godine. Tischbeinov je perspektivni crtež predočio kutiju s koje je otklonjena stranica sučeljena očima promatrača. U toj je kutiji uprizorena soba bez namještaja i rasvjetnih tijela, nastanjena mladim misliocem čija su leđa obasjana svjetlom vatre iz kamina na koji se naslanja. Nad kaminom je ogledalo u kojemu se zrcali velika tamna sjena s praznog frontalnog zida sobe. Sjena misliočeva tijela naslonjena na kamin ugrađen u lijevom bočnom zidu sobe započinje na vrhu njegovih stopala, uspinje se čitavom visinom nasuprotnog zida s ovješenim, uramljenim slikama, prelazi na strop, da bi se tu, nad kaminom, spojila s velikom sjenom čiji se manji dio zrcali u ogledalu iza njegovih leđa. Mislilac, glave podbočene dlanom desne ruke koja se laktom oslanja na lijevu podlakticu, ne gleda u slike pred sobom, nego u tlo.

Sjećate li se da je des Esseintes naposljetku odlučio zidove dati uvezati kao knjige, u maroken sprešane zrnate površine-u kožu iz Capea, uglačanu pod snažnim pritiskom debelih čeličnih ploča?

Kvadratična putanja sjena u Tischbeinovu akvarelu podsjeća me na drvenu rešetkastu konstrukciju orgulja koje sam vidjela na fotografiji reproduciranoj u Orisu uz vaš razgovor s Ješom. Posrijedi su specijalno sagrađene orgulje sa samo šest cijevi smještene u srednjovjekovnoj crkvi sv. Bucharda u Halberstadtu gdje je 5. rujna 2001. tišinom započela izvedba Cageove kompozicije ASLP (as slow as possible). 
Tišina je, kažete, potrajala do prvog akorda 5. veljače 2003., a izvedba će trajati više od šesto godina. Vaš prijatelj, arhitekt Greiner, piše Vam da je „stanovnik dalekih zvijezda izabrao ovdje svoju nastambu na zemlji, svoj kavez, mali Cage”.

U Tischbeinovu akvarelu prepoznajem mislioca koji je izabrao svoj kavez. Kažete da ste bili čovjek koji je više hodao po sobi nego po svijetu, koji je više mislio nego živio. Kažete i da Cagea niste nikada vidjeli, a bio je u Zagrebu 1961. godine u Jevšovarovu atelijeru. Imala sam sreće vidjeti ga i čuti mu glas. U Zagrebu 1985. U Maloj dvorani Lisinski, sjedio je s lijeve strane pozornice i izgovarao Finnegans Wake. Završava riječima A way a lone a last a loved a long the i počinje s Riverrun, past Eve and Adam's, from swerve of shore to bend of bay, brings us by a commodius vicus of recirculation back to Howth Castle and Environs. A Vi ste zapisali: Otići daleko po TAO znači vratiti se.

Je li Montaigne otišao po TAO? Vinja napominje ovako: „12. lipnja 1580. Montaigne napušta za čitavu godinu i pol mir i spokoj svoje 'librairie' u koju se povukao deset godina ranije dok je još bio u punoj snazi i zdravlju, ali razočaran dvorskim obvezama i javnim službama. Književni su povjesničari često ponavljali pitanje koji su ga razlozi naveli da za tako dugo vrijeme napusti svoj dom i navlastito svoju kulu u kojoj je proveo najljepše i najplodnije dane svoga života." Poput Goethea i Tischbeina dva stoljeća poslije, i on putuje Italijom. Objašnjavajući kako ego nema supstanciju, Taisen Deshimaru podsjeća na Montaigneovo priznanje da su svi gledali izvan sebe dok je on želio gledati unutra.

Istinska duboka tišina.

Kažete da stanuje na Račićevu čelu i da je zelena kao trava. I prisvajate Montherlantovu misao: Učiniti malo, ne pisati suviše, ne čitati previše, ne poznavati prevelik broj ljudi. Odbijati bez prestanka. I tako ste s razlogom, skupa s perspektivom ukinuli i retrospektivu. Zapisujete: Umor od slike. Slikarstvo teži svom ukinuću.

Detektirajući u Vašem djelu „koherenciju difuznog”, Mifka zaključuje kako se „mnoštvo pojava predmeta skuplja u sumi jedne crte koja ne dijeli postojeće od nepostojećeg, već ih izjednačava u trajanju." Dvadesetak godina poslije napisala je Sonatu za Wittgensteina:

Ponekad se vidi prašina na staklu, Pejzaž iza njega,

Nikad staklo samo.

Zapisujete: Od Duchampovog pisoara pojam umjetnosti postaje upitan, svaki pokušaj da se definira osuđen je na propast. I nacrtali ste mu kadu otvorenu gorgonskom crnom koja zaposjeda gornji brid kadra. Charlotte Corday već je odavno napustila prizorište.

Vaše pismo upućeno Ljerki Mifki, pronađeno u jednom zagrebačkom antikvarijatu, daje naslutiti da Gorgona ni Duchampa nije ostavljala ravnodušnim. Na ukinutoj retrospektivi dvije stranice toga pisma razdvojili ste ili, preciznije, spojili fotografijom Rrose Sélavy. Sinkopa posred koherencije difuznoga? Kažete da Vas je u Stockholmu, prije mnogo godina, netko ljubazno primio i pokazao Vam Duchampovo razbijeno staklo koje je skupljalo prašinu. Primjećujem da ste mramorne kockice oslobodili iz krletke i zamijenili ih šećernima. Tako je u utoru beskonačne linije kihanje izjednačeno u trajanju. 
Neodoljiva potreba za klasifikacijom dovela je do toga da se Duchampa proglasi postmodernim. Izdvojili ste Baudrillardovu tvrdnju: Postmoderna nema značenja. Nemoguće je odrediti što se sada događa. Postoji praznina i ja je propitujem. Zapisujete da slikarstvu preostaje da živi svoju nemogućnost. Baudrillard je pisao o nasilju počinjenom slici. Ovako: Slika po sebi nije povezana ni s istinom ni sa stvarnošću, ona je privid i povezana je s prividom. U tome je njezina magijska veza s iluzijom svijeta onakvim kakav jest, onom koja nas podsjeća da stvarno, kao ono najgore, nikada nije izvjesno te da svijet od nje može stvoriti ekonomiju, baš kao i načelo stvarnosti. Time se vraćamo na Laternu magicu.

Prošle sam jeseni u madridskom CaixaForumu vidjela Mélièsovu izložbu. Vrvjela je laternama magicama. Uopće me ne čudi da je taj mađioničar već 1899. godine snimio prvi politički angažirani, i stoga cenzurirani, film u povijesti kinematografije. U zgradi udaljenoj desetak minuta hoda od Caixe stanuju Las Meninas koje danas prepoznajem u Vašoj Laterni magici. Onoj koja već šezdeset godina počiva u miru jednog riječkog podruma. Poput Velázquezove slike, potpuno svjesna da živi vlastitu nemogućnost. Zbog toga je i dvorski slikar Filipa IV. dokinuo perspektivu. A onda ste upravo Vi odali počast Manetu. Beskonačnim štapom.

Grimizni zastor iz Velázquezova zrcala obitava u Laterni magici zato što je Gorgonin početak određen da bude bez razvoja. To je njena stvarnost u kojoj se zbivanja prožeta vibracijama ponekad ponavljaju. Započinjući svoju arheologiju humanističkih znanosti Foucault kaže da se u svijetloj dubini tog ogledala ne ogleda vidljivo; ono bi, doduše, moglo biti savršen dvojnik, ali u njemu se ne vidi ništa od onoga što sama slika predstavlja. Ne izlagati, zapisujete. Treba samo isprazniti prostor, ne napuniti ga. Da bi postalo moguće propitivati prazninu. Koja je oduvijek bila Vaša temeljna preokupacija.

U Cocteauovu filmu put prema Euridiki vodi kroz ogledalo. On pritom navlači gumene rukavice da bi dotaknuo njegovu glatku površinu. U Vašoj Studiji prema Masacciu gledam kako Jeronimova rukavica postaje Goyin pas. Naslikao ga je na unutrašnjem zidu vlastite kuće. Quinta del Sordo. Istinska duboka tišina?

Pročitala sam da je Miró za svojeg zadnjeg posjeta Pradu htio vidjeti samo dvije slike: Psa i Las Meninas. Ispisujete njegove rečenice: Uvijek me jako impresioniralo ono što je golo, prazni prostori, puste doline. Posebno me zadivljuje nepokretnost. U čast Račiću naslikali ste kredom i pastelom Nature morte. Devet godina poslije Norman Bryson ustvrdit će da je odstranjivanje ljudskog tijela udarni i utemeljujući čin žanra mrtve prirode. U tome prepoznaje napad na vrijednost i prestiž ljudskog subjekta. Fizičko isključivanje samo je prva od negacija svojevrsnog humanocentričnog dostojanstva koje se obično pronalazi u drugim žanrovima. Ljudska prisutnost nije samo fizički prognana; mrtva priroda prognala je također i vrijednosti koje ljudska prisutnost nameće svijetu.

Za vrijeme svojeg drugog putovanja u Italiju Velázquez je naslikao Inocenta X. Na grimiznom zastoru iza njegovih leđa prebiva velika crna sjena obrubljujući i papino desno uho. Više od dvadeset godina Bacon je opsesivno slikao Velázquezovu sliku. Vrištećeg Inocenta u kavezu. Naslikao je i psa. Nad rešetkom. I s čovječjom sjenom. Onda se u zastoru s Vaše Nature morte dogodila koherencija difuznoga izjednačivši u trajanju Velázquezovu grimiznu i Baconovu ljubičastu. Iz odsjaja Račićeva čela.

Godine 1869. postaje kažnjeničkom kolonijom. I ponovo Cioran: Rođen sam u malom gradu, u narodu bez sreće. Te iste godine Manet je na Pariškom salonu izložio Balkon. Zolin portret s knjigom, Olimpijom i samurajem naslikao je godinu dana prije. Iz misli za lipanj, srpanj, kolovoz ponovno progovara Montherlantova 
bilježnica: Budistički svećenici žive sami ljeti, okupljaju se zimi. Godine 1911. Nasta Rojc naslikala je Putnika. Prednji i stražnji plan slike fokusirani su ekstremno bliskim motrištem, dok je srednji, koji sadrži prikaz mikroskopski sitne ljudske figure, artikuliran krajnje udaljenim motrištem, poputekspandirajuće točke iščezavanja. Kao i Vaša Laterna magica, njezin Putnik, zapravo autoportret, već stotinjak godina počiva u miru depoa zagrebačke Moderne galerije. Poslije je slikala zimske pejzaže.

Ono što stvorite prije ili kasnije okrene se protiv vas, postaje vaša Golgota. Vjerujete li doista u to? Meni više zvuči kao patetična dosjetka. Daleko mi je draža Vaša napomena uz sadržaj šestog broja. Reproducirati Mona Lisu isto je što i ostaviti praznu stranicu.

Spomenuta me slika naučila shvatiti razliku između materije i fame. Titrale su joj čestice kože na licu. Gušće nego što boja titra u Rothkovoj slici kad je se osvijetli indirektno, refleksijom s bijelog podnožja. Slično se ponaša i bjelina, koja to zapravo i nije, u Vašoj Nature morte. Nepomičnost, međutim, stanuje negdje drugdje.

U nevidljivosti onoga što Madonina šaka lijeve ruke zgrčenih prstiju potiskuje prema ispruženom kažiprstu arkanđela Uriela odjevenog u crvenu haljinu. Crvenu poput prsluka Maljevičeve Radnice koja nešto nevidljivo i teško nosi u rukama. Prazninu istinske duboke tišine. Tako sam u trajanju od 1483. do 1933. shvatila suprematizam. Yvesa Kleina još uvijek nisam. vama je uzvratio pogled.

S osobitim poštovanjem, 